\title{
ОСОБЕННОСТИ ДОПРОСА СВИДЕТЕЛЕЙ И ПОТЕРПЕВШИХ В СУДЕ, В УСЛОВИЯХ ИСКЛЮЧАЮЩИХ ВИЗУАЛЬНОЕ НАБЛЮДЕНИЕ
}

\begin{abstract}
Аннотация: Общие гарантии уголовного процесса обеспечивают комплекс условий, которые способствуют всестороннему и объективному производству по уголовному делу. Дальнейшее продолжение гарантии находят в мерах обеспечения, в частности, прав и свобод человека и гражданина в уголовном судопроизводстве. Проблема реализачии принципа охраны прав и свобод человека и гражданина связана с гарантиями субъективных прав и законных интересов личности. Одной из основных гарантий свидетеля и потерпевшего по уголовному делу является обеспечение безопасности в ходе всего производства по уголовному делу, в том числе и в стадии судебного производства. Данная безопасность должна выражаться не только в мерах защиты, но и обеспечиваться психологическая поддержка
\end{abstract}

Ключевые слова: Юриспруденция, свидетель, потерпевший, допрос, безопасность, визуальное наблюдение, холерик, меланхолик, сангвиник, флегматик

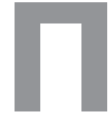
сихологические особенности судебного процесса при рассмотрении уголовных дел связываются с поведением участников уголовного судопроизводства в процессе судебного разбирательства, в частности при допросе свидетелей и потерпевших, в случаях, исключающих визуальное наблюдение.

Анализ проблем допроса потерпевших и свидетелей, в условиях, исключающих визуальное наблюдение, связано с разработкой рекомендаций, направленных на решение задач и проблем при применении мер безопасности в отношении участников уголовного судопроизводства.

Однако характер мер безопасности на судебных стадиях имеет свои особенности, вызванные целями и задачами судебного разбирательства, проводимого в условиях действия принципов состязательности сторон и непосредственного рассмотрения доказательств в судебном следствии. Из этого вытекают две параллельно решаемые судом задачи: 1) обеспечение эффективности и реальности принимаемых мер безопасности в отношении участников уголовного процесса; 2) отсутствие негативного влияния указанных мер на степень исследования и результаты оценки доказательств в суде. ${ }^{1}$ Многие ученые считают, что применение мер безопасности является нарушением принципов состязательности и равноправия сторон, непосредственности и устности судебного разбирательства, нарушает право подсудимого на защиту,

\footnotetext{
${ }^{1}$ Халиков А. Обеспечение безопасности участников уголовного судопроизводства в стадии судебного разбирательства // Уголовное право. - 2008. - № 4. - С. 17.
}

лишает его и защитника права на полноценное участие в исследовании доказательств. ${ }^{2}$ При этом по их мнению, чем больше объем сокрываемой информации о свидетеле или потерпевшем, тем больше происходит ущемление прав обвиняемого. В соответствии со ст. 47 УПК РФ обвиняемый вправе знать, в чем он обвиняется. Очевидно, что данное положение предполагает право обвиняемого знать, кем он обвиняется. Потерпевший входит в состав участников со стороны обвинения и уголовного преследования. Анонимный свидетель, безусловно, также является свидетелем обвинения - в противном случае нет смысла в сокрытии его личности. Следовательно, анонимный потерпевший и свидетель обвинения участвуют в деятельности по обвинению.

Таким образом, сокрытие сведений о личности потерпевшего и свидетеля обвинения, несомненно, в известном смысле нарушает право обвиняемого знать, в чем и кем он обвиняется. Следует отметить, что практика дачи показаний под псевдонимом широко распространена в зарубежных странах. Европейский Суд по правам человека допускает участие в уголовном судопроизводстве свидетелей под псевдонимом. Решением Европейского Суда по правам человека признано, что использование сведений, представленных анонимными свидетелями в качестве доказательств на этапе досудебного расследования, согласуется с положениями Европейской конвенции по правам человека и является обязательным для государствчленов Совета Европы, участником которого стала

\footnotetext{
${ }^{2}$ Стеиовский Ю.И. Судебная власть. - М.: Дело, 2000. - С. 149.
} 
DOI: $10.7256 / 1811-9018.2013 .7 .4933$

При цитировании этой статьи сноска на dоі обязательна

\section{Право и политика 7 (163) • 2013}

и Россия. При этом одновременно Европейский Суд подчеркивает невозможность вынесения приговора только на основании показаний таких свидетелей. В любом случае они должны быть подтверждены в суде и другими доказательствами. ${ }^{3}$

Вопрос о возможности участия в уголовном судопроизводстве свидетелей под псевдонимом стал предметом рассмотрения и Конституционного Суда РФ. В Определении от 21 апреля 2005 г. № 240-О «Об отказе в принятии к рассмотрению жалобы гражданина Ермакова Михаила Борисовича на нарушение его конституционных прав частью 9 статьи 166, частью пятой статьи 193 и частью пятой статьи 278 УПК РФ» Конституционный Суд РФ указал, что допрос лица под псевдонимом применяется в целях борьбы с преступностью и обеспечения защиты прав и законных интересов граждан; при этом должны быть предприняты меры, обеспечивающие пропорциональность связанных с использованием таких средств ограничений права на защиту и преследуемой цели. Для обоснования собственной позиции Конституционный Суд РФ сослался на отдельные нормы международного права - ст. 22 Конвенции об уголовной ответственности за коррупцию, ст. 24 Конвенции против транснациональной организованной преступности, ст.ст. 32 и 33 Конвенции против коррупции, на Руководящие принципы Совета Европы в области прав человека и борьбы с терроризмом. В Определении по данному делу Конституционный Суд РФ сделал вывод о том, что использование в доказывании показаний анонимных свидетелей является законным. При этом стороне защиты представлены определенные права. Лишь в виде исключения допускается возможность раскрытия данных о свидетеле по ходатайствам сторон (ч. 6 ст. 278 УПК РФ).

Исследователями и практиками неоднократно подчеркивалась зависимость эффективности подтверждения доказательств в суде от уровня научно-технического прогресса и возможности внедрения в уголовное судопроизводство информационных достижений. ${ }^{4}$ Так, 17 июля 2006 г. в Верховном суде Республики Татарстан завершился судебный процесс в отношении участников банды «29 комплекс» (г. Набережные Челны),

\footnotetext{
${ }^{3}$ Брусницын Л.В. Потерпевшие и свидетели под псевдонимом: национальное законодательство и прецеденты Европейского Суда по правам человека // Уголовное право. - 2002. - № 2. - С. 125-127.

${ }^{4}$ Беляев М.В. Расследование и судебное разбирательство дел о бандитизме: уголовно-процессуальные и криминалистические вопросы. - Казань: Казан. гос. ун-т, 2009. - С. 140; Сидорова Н.В. Показания свидетеля в российском уголовном процессе: Учеб. пособие. - Тюмень: Изд-во Тюмен. гос. ун-та, 2007. - С. 91.
}

длившийся 1 год и 8 месяцев. ${ }^{5}$ Перед судом предстали 32 подсудимых, обвинявшихся в создании и участии в банде, многочисленных убийствах, похищениях людей, вымогательствах, совершении преступлений экономической направленности. ${ }^{6}$ Ко многим свидетелям были применены меры безопасности, предусмотренные законом, в частности, допрос зашифрованных свидетелей в условиях, исключающих визуальное наблюдение. В связи с чем, допрос производился с соответствующим комплектом микрофонов и громкоговорителей, а также телевизора и большого проекционного экрана с проектором.

Использование технических средств является наиболее надежным способом обеспечения защиты лица, участвующего в судебном разбирательстве. Они позволяют исключить идентификацию защищаемого лица присутствующими в зале при помощи видеопомех, изменения голоса и устранить возможность установления его места жительства. ${ }^{7}$

Однако необходимо остановиться на скрытой стороне свидетельских показаний при допросе, исключающем визуальное наблюдение.

Как цитирует Н.В. Кондратьева «первой задачей при допросе .... является создание у допрашиваемого благожелательного и откровенного к себе отношения, что достигается безукоризненной вежливостью и мягкостью обращения». ${ }^{8}$ При производстве допроса в суде с допрашиваемым выстраиваются определенные психологические отношения, направленные на получение достоверных сведений, доказательств без психологического давления и боязни давления со стороны обвиняемого. Психология общения в суде с потерпевшим, свидетелем при применении мер безопасности и допросе в условиях, исключающих визуальное наблюдение имеет важное процессуальное и психологическое значение. Успешный исход судебного разбирательства зачастую зависит от того, какие показания при допросе и в какой форме даст потерпевший или свидетель. Многие ученые отмечают, что необходимым условием, сопровождающим допрос является установление психологического контакта. ${ }^{9}$

Интенсивные исследования и обсуждения вопросов, связанных с отношением к свидетельским пока-

\footnotetext{
${ }^{5}$ Уголовное дело № 2-5/2006 // Архив Верховного Суда Республики Татарстан за 2006 г.

${ }^{6}$ Беляев М.В. Указ. соч. - С. 140-141.

${ }^{7}$ Новикова М.В. Институт безопасности в уголовном судопроизводстве и пути его совершенствования // Российский судья. -2007. - № 7. - С. $38-41$.

${ }^{8}$ Якимов И.Н., Михеев П.П. Допрос. - М., 1930 г. - С. 29

9 Зорин Г.А. Руководство по тактике допроса. - М., 2001. - С. 235
} 
заниям, можно проследить в трудах О. Гольдовского «Психология свидетельских показаний», А.Ф. Кони «Свидетельские показания на суде». ${ }^{10}$

Среди криминалистов не установилось единого мнения, на чем должна быть основана тактика установления психологического контакта. В.Л. Васьльев усматривает зависимость качества показаний от типа темперамента допрашиваемого, поскольку одни и те же аргументы с разной силой действуют на людей разных типов.

В данном случае речь идет о специфике изложения свидетельских показаний человеком, находящимся под защитой, голос которого изменяется компьютерной техникой. Ведь каждую личность характеризуют определенные признаки, по которым можно его идентифицировать. Здесь речь, несомненно, идет о таких признаках, как темперамент, пол, возраст, поведение свидетеля. При допросе, исключающем визуальное наблюдение с применением техники изменения голоса, свидетель, дающий показания, может быть сангвиником (может сильно волноваться, показывать личные переживания, граничащие с преувеличением и искажением фактов), меланхоликом (драматизировать события, быть склонным к подавленности, грусти), холериком (быть невнимательным, с поверхностным взглядом, эмоционально-взрывоопасный), флегматиком (нежелающим исполнять свидетельский долг, характеризуется медлительностью, низким уровнем психической активности, невыразительностью). Данные признаки характера личности не скроешь техникой, изменяющей голос. Необходимо отметить и некоторые признаки, выдающие пол свидетеля. У мужчин более развиты обоняние, слух, зрение; у женщин - вкус, вазомоторная возбудимость. Мужчинам время кажется длиннее на $35 \%$, а женщинам - на $111 \% .^{11}$

Возраст свидетеля при допросе также имеет немаловажное значение. Память стариков сохраняет воспоминания многих лет давности, не уделяя достаточного внимания событиям ближайшего времени. Дети, напротив, ближайшие факты помнят лучше.

Поведение свидетеля зависит от его умственных качеств. Например, может быть глупым по природе, использует определенные речевые обороты в разговоре, а также своеобразность, которая может отразиться на показаниях и их изложении.

Зачастую из-за неиформированности свидетеля, отсутствия должного контроля со стороны следствия и несоблюдения процессуальных обязанностей происходят негативные ситуации, в ходе которых утра-

\footnotetext{
${ }^{10}$ Кони А.Ф. Избранные произведения. - М., 1965. - С. 160.

${ }^{11}$ Васильев В.Л. Юридическая психология: Учебник для вузов. -
} СПб.: Питер, 2009. - С. 557. чиваются важнейшие доказательства по делу. Таким примером может служить случай, имевший место при расследовании уголовного дела о бандитизме. Так, участник одной из казанских банд С. обвинялся в убийстве из автомата трех человек. В ходе раскрытия данного преступления было установлено, что свидетель Ц., со слов самого С., полностью осведомлен о совершенном преступлении. При допросе Ц. было разъяснено его процессуальное положение и предложено под измененными анкетными данными рассказать о случившемся. Согласившись на данное предложение, Ц. под другой фамилией на предварительном следствии дал показания, изобличающие С. В судебное заседание Ц. не явился из-за страха быть расшифрованным участником банды. Неявка Ц. в суд существенно ослабляла собранную по данному делу доказательственную базу. Исполняя поручение следователя, расследовавшего уголовное дело, сотрудники милиции установили местонахождение Ц. и доставили его в суд. Не имея представления о процессуальном положении Ц., о ценности его показаний и не зная о ранее примененных к нему мерах безопасности, сотрудники милиции буквально втолкнули свидетеля в зал суда. На вопрос о фамилии Ц. вынужденно назвал свою подлинную фамилию и полностью отказался от показаний, данных им под другой фамилией. В результате были утрачены ценнейшие свидетельские показания, которые могли стать ключевым доказательством по данному делу, a C. был оправдан судом. ${ }^{12}$ Причем, ответственность лиц, которым стали известны данные о защищаемом лице, предусмотрена ст. 26 Федерального закона от 20 августа 2004 г. № 119-Ф3 «О государственной защите потерпевших, свидетелей и иных участников уголовного судопроизводства», в которой отмечается, что «разглашение сведений о защищаемом лице и применяемых в отношении его мерах безопасности лицом, которому эти сведения были доверены или стали известны в связи с его служебной деятельностью, влечет за собой ответственность, предусмотренную законодательством Российской Федерации».

Обратимся к вышеприведенному разбирательству в суде. Сотрудники милиции не были никоим образом посвящены во все тонкости защиты указанного лица и применяемых к нему мерах безопасности, они не разглашали сведений, однако важнейшие показания по делу были утрачены.

Таким образом, можно отметить несовершенство законодательства в части порядка допроса свидетеля в суде, в условиях исключающих визуальное наблюдение, в частности, не определен конкретный перечень

\footnotetext{
${ }^{12}$ Уголовное дело № 119344 // Архив Прокуратуры Республики
} Татарстан за 1999 г. 
DOI: $10.7256 / 1811-9018.2013 .7 .4933$

При цитировании этой статьи сноска на dоі обязательна

\section{Право и политика 7 (163) 2013}

условий. К ним можно отнести удаленный допрос, допрос с изменением голоса и т.д.

B.T. Томин отмечает: «Чудовищно, если в уголовном процессе станут пренебрегать интересами личностей, в него вовлекаемых, но не менее чудовищно, если уголовное судопроизводство как одна из отраслей правоохранительной деятельности уйдет от своей обязанности защищать не только интересы, но и саму жизнь законопослушного гражданина». ${ }^{13}$ Тем самым мы приходим к проблеме ценности жизни: все началось с банальной забывчивости, а закончилось утратой не только главного показания, но иногда и человеческой жизни. Следует добавить, что в России ежегодно от убийств погибают в среднем 30 тысяч человек. Приведенная статистика свидетельствует о низкой ценности человеческой жизни в нашей стране. Ведь за лицами, привлекаемыми в качестве свидетелей или потерпевшими, участвующими в уголовном деле, стоит множество людей, кому их судьба небезразлична, и которые сами становятся жертвами от безответственности, пренебрежения уголовно-процессуальным законом и мерами предосторожности.

Если потерпевший и свидетель были допрошены под псевдонимом в стадии предварительного расследования и основания применения данной меры безопасности с началом судебного производства не отпали, в суде данные лица в обязательном порядке должны допрашиваться под псевдонимом и в условиях, исключающих их визуальное наблюдение другими участниками уголовного судопроизводства, что, конечно, не снимает с суда обязанность согласно ч. 5 ст. 278 УПК РФ вынести мотивированное определение (постановление) о производстве допроса в этих условиях. Производство допроса в указанных условиях без соответствующего постановления стало одним из оснований отмены обвинительного приговора. ${ }^{14}$ В условиях, предусмотренных ч. 5 ст. 278 УПК РФ, может быть допрошен и человек, который ранее (в ходе предварительного расследования или предшествовавших судебных заседаний) не допрашивался. Такой допрос осуществляется по определению (постановлению) суда, инициированному самим судом, ходатайством государственного обвинителя либо указанного человека. Вызов в суд лица, участвующего в уголовном судопроизводстве под псевдонимом, не должен производиться в обычном порядке, т.е. повесткой, оформляемой секретарем судебного заседания,

${ }^{13}$ Томин В.Т. Острые углы уголовного судопроизводства. - М., 1991. - C. 24-25.

${ }^{14}$ Определение Судебной коллегии по уголовным делам Верховного Суда РФ от 8 июля 2004 г. № 32-О04-37сп // БВС РФ. - 2005. - № 8. - C. 21-22. поскольку это сопряжено с вскрытием им конверта, в котором хранится постановление о предоставлении защищаемому лицу псевдонима, и с ознакомлением с подлинными сведениями о защищаемом не только секретаря, но, возможно, и иных лиц, что чревато возникновением опасности для защищаемого.

Безопасность защищаемого лица может быть обеспечена при условии, если маршруты его доставки в судебное заседание и удаления из суда не станут известны посторонним. Очевидно, что в решении этого вопроса должны принимать участие судья, в производстве которого находится уголовное дело, судебные приставы и представители органа, которым было проведено предварительное расследование, а при необходимости сотрудники и иных подразделений правоохранительных органов, в том числе осуществляющих ОРД. Если допрос в предусмотренных ч. 5 ст. 278 УПК РФ условиях предполагается провести вне здания суда, то необходимо принять меры, исключающие возможность скрытного следования за судьями членов преступных групп (такие попытки отмечаются в практике) с целью установления места допроса и личности защищаемого. В ч. 5 ст. 278 УПК РФ не указан способ, исключающий визуальное наблюдение допрашиваемого другими участниками уголовного судопроизводства, поэтому возможны, в частности: удаление из зала судебного заседания всех его участников, кроме судьи (судей) и подлежащего допросу лица; допрос защищаемого судьей (судьями) вне зала судебного заседания (в другом помещении, которое может находиться как в здании суда, так и вне этого здания); производство допроса с использованием средств прямой видеосвязи (видеотрансляции). В последнем случае судьи будут находиться в зале судебного заседания, а защищаемый - в другом помещении, при этом должны применяться видео-и аудиопомехи, исключающие возможность узнавания лица, скрываемого под псевдонимом, находящимися в зале суда, судьи же могут удостовериться в его личности до начала допроса. Применение таких помех, в том числе с помощью компьютерных программ, признано допустимым Верховным Судом РФ. ${ }^{15}$ При этом аудиопомехи должны исключать возможность идентификации защищаемого лица и по присущим ему особенностям речи (из-за несоблюдения этого правила при допросе в условиях, предусмотренных ч. 5 ст. 278 УПК РФ, свидетель был узнан подсудимым по дефекту речи), а видеопомехи должны препятствовать идентификации, в том числе по характерным для защищаемого лица особенностям

\footnotetext{
${ }^{15}$ Кассационное определение Судебной коллегии по уголовным делам Верховного Суда РФ от 14 июня 2006 г. № 43-О06-9 // Правовая система «Гарант».
} 
поведения: жестам, мимике и пр. При отсутствии технических средств защищаемые допрашиваются в смежной с залом судебного заседания комнате при открытой в нее двери либо за ширмой, установленной непосредственно в зале судебного заседания. Если существует опасность идентификации защищаемого по голосу, при отсутствии специальных технических средств используются подручные средства. ${ }^{16}$

А. Епихин приводит пример судебной практики г. Воркуты о применении такой меры безопасности, как исключение визуального наблюдения. При рассмотрении уголовного дела о тяжком преступлении судья допрашивала свидетеля, находящегося за шторой зала судебного заседания. При этом свидетель, чтобы изменить свой голос, говорил в металлическую кружку, в результате чего голос действительно изменился. ${ }^{17}$ В другом случае искажение голоса достигалось использованием вместо кружки стеклянной литровой банки. ${ }^{18}$

Независимо от способа, исключающего визуальное наблюдение защищаемого лица другими участниками уголовного судопроизводства, сторонам обвинения и защиты, учитывая ч. 3 ст. 278 УПК РФ, должна быть предоставлена возможность задавать допрашиваемому вопросы. Непредоставление такой возможности повлекло отмену обвинительных приговоров в кассационном ${ }^{19}$ и надзорном порядке. ${ }^{20}$ Предоставление же стороне защиты возможности задать свидетелю вопросы и получить ответы на них (наряду с мотивированностью постановления, которым в ходе досудебного производства защищаемому свидетелю был присвоен псевдоним) обусловило вывод Судебной коллегии по уголовным делам Верховного Суда РФ о том, что нарушений уголовно-процессуального закона, влекущих отмену либо

\footnotetext{
${ }^{16}$ Брусницын Л. Псевдонимы в уголовном процессе // Законность. - 2005. - № 1 .

${ }^{17}$ Епихин А. Правовое регулирование мер безопасности участников процесса // Законность. - 2003. - № 5. - С. 47.

${ }^{18}$ Малов А.А., Тимошенко А.А. Состояние законности и проблемные аспекты применения мер государственной защиты к потерпевшим, свидетелям и иным участникам уголовного судопроизводства. М.: Ген. прокуратура РФ, 2008. - С. 17.

${ }^{19}$ Справка Управления по обеспечению участия прокуроров в рассмотрении уголовных дел судами Генеральной прокуратуры РФ о применении норм УПК РФ, обеспечивающих безопасность участников уголовного судопроизводства от 24 декабря 2003 г. исх. № 12/12-03 // Архив НИИ проблем укрепления законности и правопорядка при Генеральной прокуратуре РФ.

${ }^{20}$ Определение Судебной коллегии по уголовным делам Верховного Суда РФ от 1 марта 2005 г. № 24-Д04-9 // БВС РФ. - 2006. - № 6. - С. 29.
}

изменение обвинительного приговора, не имеется. ${ }^{21}$ В ходе аудио-и видеотрансляции вопросы могут задаваться сторонами непосредственно допрашиваемому, а последний может непосредственно в ходе трансляции отвечать на них. При использовании иных способов допроса в условиях, предусмотренных ч. 5 ст. 278 УПК РФ, вопросы задаются «письменно, с использованием технических средств или иным способом». ${ }^{22}$ Ответы на них даются также в письменном виде и оглашаются сторонам судьей. ${ }^{23}$ Независимо от способа постановки вопросов те из них, которые направлены на раскрытие личности допрашиваемого, подлежат отводу судом. Отводу подлежат также вопросы (полностью либо в соответствующей части), хотя бы прямо и не направленные на идентификацию защищаемого лица, и ответы, которые могут привести к его идентификации. Если ответ на (неотведенный) вопрос может привести к идентификации, данный ответ не подлежит оглашению и занесению в протокол судебного заседания (полностью либо в соответствующей части).

УПК РФ не содержит соответствующих предписаний, но исходя из цели использования псевдонима - сохранения в тайне личности защищаемого лица -необходимость и правомерность этих мер очевидны (тем не менее УПК РФ следует дополнить прямыми указаниями на необходимость сохранения в тайне личности защищаемого лица как на основание для отвода указанных вопросов; на неоглашение и незанесение в протокол судебного заседания ответов защищаемого лица, которые делают возможным раскрытие его подлинных данных).

В соответствии с ч. 6 ст. 278 УПК РФ стороны вправе заявить ходатайство о раскрытии подлинных сведений о лицах, участвующих в уголовном судопроизводстве под псевдонимом. Исходя из содержания ч. 6 ст. 278 УПК РФ раскрытие личности человека, участвующего в уголовном судопроизводстве под псевдонимом, возможно и в апелляционной инстанции, поскольку согласно ч. 1 ст. 365 УПК РФ производство в апелляционной инстанции осуществляется в порядке, установленном гл. 35-39 УПК РФ

\footnotetext{
${ }^{21}$ Кассационное определение Судебной коллегии по уголовным делам Верховного Суда РФ от 14 июня 2006 г. № 43-О06-9 // Правовая система «Гарант».

${ }^{22}$ Там же.

${ }^{23}$ Определение СК по уголовным делам Верховного Суда РФ от 1 марта 2005 г. № 24-Д04-9 «Каждый обвиняемый в совершении уголовного преступления согласно п. 16 ч. 4 ст. 47, ст. 247, ч. 3 ст. 278 УПК РФ вправе допрашивать показывающих против него свидетелей» (извлечение) // Бюллетень Верховного Суда Российской Федерации. - 2006. - № 6.
} 
DOI: 10.7256/1811-9018.2013.7.4933

При цитировании этой статьи сноска на dоі обязательна

\section{Право и политика 7 (163) • 2013}

с изъятиями, предусмотренными гл. 44. При этом гл. 44 каких-либо изъятий из ст. 278 УПК РФ не предусматривает.

Согласно ч. 6 ст. 278 УПК РФ в случае заявления сторонами обоснованного ходатайства о раскрытии подлинных сведений о лице суд вправе предоставить сторонам возможность ознакомления с указанными сведениями, т.е. раскрытие подлинных сведений о защищаемом лице возможно только в том случае, если заявлено указанное ходатайство. ${ }^{24}$ Исходя из содержания ч. 6 ст. 278 УПК РФ суд вправе не удовлетворить обоснованное ходатайство о раскрытии подлинных сведений. Представляется, что при разрешении такого ходатайства суд должен руководствоваться позицией человека, которому обещали защиту от преступников и потому предоставили псевдоним, т.е., если защищаемый не согласен с раскрытием сведений о нем, указанное ходатайство удовлетворению не подлежит.

В процессе работы с защищаемыми лицами подразделение государственной защиты МВД по РТ также сталкивается с проблемами коррекции психологического состояния на различных этапах применения мер безопасности (из-за испытываемого ими страха, стресса от угроз либо от факта быть очевидцем совершения убийства), в т.ч. при взятии лица под охрану, в ходе которого происходит его изоляция от родственников, друзей и знакомых, при подготовке лица к следственным действиям и к судебным заседаниям, в ходе которых, кстати, тоже может быть оказано психологическое давление со стороны родственников или защиты угрозоносителей, а также его адаптации после окончания всех следственных и судебных действий. Контингент защищаемых лиц является не простым, никто не может знать, что у них на уме. Примером тому служат случаи суицидов защищаемых лиц в г. Санкт-Петербурге и Кемеровской области. В связи с данными обстоятельствами возникла необходимость при обеспечении безопасности защищаемых лиц обеспечения психологической помощи защищаемым лицам не только на стадии предварительного расследования, но и на стадии судебного разбирательства. 24 июня 2010г. в целях организации взаимодействия с отделом психологического обеспечения МВД по РТ проведено совместное совещание, на котором доведены порядок осуществления функции государственной защиты органами внутренних дел по РТ, рассмотрены вопросы взаимодействия по данному направлению

\footnotetext{
${ }^{24}$ Брусницын Л.В. Комментарий законодательства об обеспечении безопасности участников уголовного судопроизводства. - М.: Юстицинформ, 2009. - С. 178.
}

деятельности. Обсуждались проблемы коррекции психологического состояния и реабилитации защищаемых лиц.

Таким образом, можно отметить несовершенство законодательства в части порядка допроса свидетеля, потерпевшего в суде, в условиях исключающих визуальное наблюдение, в частности, не определен конкретный перечень условий. К ним можно отнести: удаленный допрос, допрос с изменением голоса и т.д. Соответственно, не уделяется внимание и психологическим аспектам допроса в данной ситуации.

B.T. Томин отмечает: “Чудовищно, если в уголовном процессе станут пренебрегать интересами личностей, в него вовлекаемых, но не менее чудовищно, если уголовное судопроизводство как одна из отраслей правоохранительной деятельности уйдет от своей обязанности защищать не только интересы, но и саму жизнь законопослушного гражданина". ${ }^{25}$

Тем самым, мы приходим к проблеме ценности жизни: все началось с банальной забывчивости, а закончилось утратой не только главного показания, но, иногда, и человеческой жизни. Следует добавить, что в России ежегодно от убийств погибают в среднем 30 тысяч человек. Приведенная статистика свидетельствует о низкой ценности человеческой жизни в нашей стране. Ведь за лицами, привлекаемыми в качестве свидетелей или потерпевшими, участвующими в уголовном деле стоят множество людей, кому их судьба небезразлична, и которые сами становятся жертвами от безответственности, пренебрежения уголовно-процессуальным законом и мерами предосторожности.

\section{Библиография:}

1. Халиков А.Обеспечение безопасности участников уголовного судопроизводства в стадии судебного разбирательства // Уголовное право. - 2008. - № 4. - С. 17.

2. Стецовский Ю.И. Судебная власть. - М.: Дело, 2000. - С. 149.

3. Брусницын Л.В. Потерпевшие и свидетели под псевдонимом: национальное законодательство и прецеденты Европейского Суда по правам человека // Уголовное право. - 2002. - № 2. - С. 125-127.

4. Беляев М.В. Расследование и судебное разбирательство дел о бандитизме: уголовно-процессуальные и криминалистические вопросы. - Казань: Казан. гос. ун-т, 2009. - С. 140;

${ }^{25}$ Томин В.T. Острые углы уголовного судопроизводства. - М., 1991. - C. $24-25$. 
DOI: 10.7256/1811-9018.2013.7.4933

При цитировании этой статьи сноска на doi обязательна

Закон и правопорядок

5. Сидорова Н.В. Показания свидетеля в российском уголовном процессе: Учеб. пособие. - Тюмень: Изд-во Тюмен. гос. ун-та, 2007. - С. 91.

6. Уголовное дело № 2-5/2006 // Архив Верховного Суда Республики Татарстан за 2006 г.

7. Беляев М.В. Указ. соч. - С. 140-141.

8. Новикова М.В. Институт безопасности в уголовном судопроизводстве и пути его совершенствования // Российский судья. - 2007. - № 7. - С. 38-41.

9. Якимов И.Н., Михеев П.П. Допрос. - М., 1930 г. - С. 29

10. Зорин Г.А. Руководство по тактике допроса. - М., 2001. - С. 235

11. Кони А.Ф. Избранные произведения. - М., 1965. - C. 160 .

12. Васильев В.Л. Юридическая психология: Учебник для вузов. - СПб.: Питер, 2009. - С. 557.

13. Уголовное дело № 119344 // Архив Прокуратуры Республики Татарстан за 1999 г.

14. Томин В.Т. Острые углы уголовного судопроизводства. - М., 1991. - С. 24-25.

15. Определение Судебной коллегии по уголовным делам Верховного Суда РФ от 8 июля 2004 г. № 32-О04-37сп // БВС РФ. - 2005. - № 8. - С. 21-22.

16. Кассационное определение Судебной коллегии по уголовным делам Верховного Суда РФ от 14 июня 2006 г. № 43-О06-9 // Правовая система «Гарант».

17. Брусницын Л. Псевдонимы в уголовном процессе // Законность. - 2005. - № 1 .

18. Епихин А. Правовое регулирование мер безопасности участников процесса // Законность. - 2003. - № 5. - С. 47.

19. Малов А.А., Тимошенко А.А. Состояние законности и проблемные аспекты применения мер государственной защиты к потерпевшим, свидетелям и иным участникам уголовного судопроизводства. - М.: Ген. прокуратура РФ, 2008. - С. 17.

20. Справка Управления по обеспечению участия прокуроров в рассмотрении уголовных дел судами Генеральной прокуратуры РФ о применении норм УПК РФ, обеспечивающих безопасность участников уголовного судопроизводства от 24 декабря 2003 г. исх. № 12/12-03 // Архив НИИ проблем укрепления законности и правопорядка при Генеральной прокуратуре РФ.

21. Определение Судебной коллегии по уголовным делам Верховного Суда РФ от 1 марта 2005 г. № 24-Д04-9 // БВС РФ. - 2006. - № 6. - С. 29.

22. Кассационное определение Судебной коллегии по уголовным делам Верховного Суда РФ от 14 июня 2006 г. № 43-О06-9 // Правовая система «Гарант».

23. Определение СК по уголовным делам Верховного Суда РФ от 1 марта 2005 г. № 24-Д04-9 «Каждый обвиняемый в совершении уголовного преступления согласно п. 16 ч. 4 ст. 47, ст. 247, ч. 3 ст. 278 УПК РФ вправе допрашивать показывающих против него свидетелей» (извлечение) // Бюллетень Верховного Суда Российской Федерации. - 2006. - № 6 .

24. Брусницын Л.В. Комментарий законодательства об обеспечении безопасности участников уголовного судопроизводства. - М.: Юстицинформ, 2009. - С. 178.

25. Томин В.Т. Острые углы уголовного судопроизводства. - М., 1991. - С. $24-25$.

\section{References (transliteration):}

1. Halikov A.Obespechenie bezopasnosti uchastnikov ugolovnogo sudoproizvodstva $\mathrm{v}$ stadii sudebnogo razbiratel'stva // Ugolovnoe pravo. - 2008. - № 4. - S. 17.

2. Stecovskiy Yu.I. Sudebnaya vlast'. - M.: Delo, 2000. - S. 149.

3. Brusnicyn L.V. Poterpevshie i svideteli pod psevdonimom: nacional'noe zakonodatel'stvo i precedenty Evropeyskogo Suda po pravam cheloveka // Ugolovnoe pravo. - 2002. - № 2. S. $125-127$.

4. Belyaev M.V. Rassledovanie i sudebnoe razbiratel'stvo del o banditizme: ugolovno-processual'nye i kriminalisticheskie voprosy. - Kazan': Kazan. gos. un-t, 2009. - S. 140;

5. Sidorova N.V. Pokazaniya svidetelya $\mathrm{v}$ rossiyskom ugolovnom processe: Ucheb. posobie. - Tyumen': Izd-vo Tyumen. gos. un-ta, 2007. - S. 91.

6. Belyaev M.V. Ukaz. soch. - S. 140-141.

7. Novikova M.V. Institut bezopasnosti v ugolovnom sudoproizvodstve i puti ego sovershenstvovaniya // Rossiyskiy sud'ya. - 2007. - № 7. - S. 38-41.

8. Yakimov I.N., Miheev P.P. Dopros. - M., 1930 g. - S. 29

9. Zorin G.A. Rukovodstvo po taktike doprosa. - M., 2001. - S. 235

10. Koni A.F. Izbrannye proizvedeniya. - M., 1965. -

11. S. 160 .

12. Vasil'ev V.L. Yuridicheskaya psihologiya: Uchebnik dlya vuzov. - SPb.: Piter, 2009. - S. 557.

13. Tomin V.T. Ostrye ugly ugolovnogo sudoproizvodstva. - M., 1991. - S. 24-25.

14. Brusnicyn L. Psevdonimy v ugolovnom processe // Zakonnost'. - 2005. - № 1 .

15. Epihin A. Pravovoe regulirovanie mer bezopasnosti uchastnikov processa // Zakonnost'. - 2003. - № 5. - S. 47. 
DOI: 10.7256/1811-9018.2013.7.4933

При цитировании этой статьи сноска на dоі обязательна

\section{Право и политика $7(163) \cdot 2013$}

16. Malov A.A., Timoshenko A.A. Sostoyanie zakonnosti i problemnye aspekty primeneniya mer gosudarstvennoy zaschity k poterpevshim, svidetelyam i inym uchastnikam ugolovnogo sudoproizvodstva. - M.: Gen. prokuratura RF, 2008. - S. 17.
17. Brusnicyn L.V. Kommentariy zakonodatel'stva ob obespechenii bezopasnosti uchastnikov ugolovnogo sudoproizvodstva. - M.: Yusticinform, 2009. - S. 178.

18. Tomin V.T. Ostrye ugly ugolovnogo sudoproizvodstva. - M., 1991. - S. $24-25$. 